\title{
CONSUMER NEGATIVITY TOWARDS BRANDS: BRAND HATE OR BRAND SWITCH?
}

\author{
DOI: 10.17261/Pressacademia.2019.1070 \\ PAP-V.9-2019(17)-p.78-80
}

\section{Fatih Pinarbasi ${ }^{1}$, Ebru Enginkaya ${ }^{2}$}

${ }^{1}$ Istanbul Medipol University, School of Business and Management, Beykoz, Istanbul, Turkey fpinarbasi@medipol.edu.tr, ORCID: 0000-0001-9005-0324

${ }^{2} Y_{\text {IId }}$ Iz Technical University, Department of Business Administration, Esenler, Istanbul, Turkey engink@yildiz.edu.tr, ORCID: 0000-0003-1137-3470

To cite this document

Pinarbasi, F., Enginkaya, E., (2019). Consumer negativity towards brands: brand hate or brand switch?. PressAcademia Procedia (PAP), V.9, p.78-80

Permemant link to this document: http://doi.org/10.17261/Pressacademia.2019.1070

Copyright: Published by PressAcademia and limited licenced re-use rights only.

\begin{abstract}
Purpose- Consumer negativity is one of crucial concepts for understanding and evaluating consumers in today's world, since emotions play key role for consumer decision making. The study aims to examine consumer negativity with related concepts (brand hate and brand switch) in Turkey context.

Methodology- A survey with 135 participants is used for data collection stage and study employs logistic regression and Mann Whitney Tests for methodology according to non-parametric structure of data.

Findings- Results imply that all antecedent variables (negative past experience, symbolic incongruity and ideological incongruity) have positive relationship with brand hate, while only negative past experience and symbolic incongruity have positive relationship with brand switch. Mann Whitney tests also conclude that negative e-wom has significant differences regarding to brand hate and brand switch variables.

Conclusion- Study included descriptive statistics regarding to Turkish consumer negativity for managerial implication. The study confirms antecedents of brand hate regarding to previous studies, while it implies ideological incongruity as most important antecedent. Brand switch concept is only affected by negative past experience and symbolic incongruity, this shows that ideological incongruity does not affect brand switch intention. Ideological incongruity is found important for concept with attitude nature (brand hate) while opposite conclusion is valid for concept with intention nature (brand switch).
\end{abstract}

Keywords: Consumer negativity, brand negativity, brand hate, brand avoidance, brand relationship JEL Codes: M31

\section{INTRODUCTION}

The rapid change and globalization in the world are affecting consumer behavior intensively. Communication technologies, social media and internet affect behaviour patterns of consumer in today's world. As result of the changes, human beings have "faster" lives. In this new lifestyle, emotions are affected by changes in terms of forms and expression styles.

The fact that human beings who can live more intense emotions than the old period and express themselves in consumer behaviors will be the basis of this research. General reactions of consumer (Pınarbaşı \& Canbolat, 2018) or negative reactions of consumer (Canbolat \& Pınarbaşı, 2018) can be focus of consumer-brand relationship studies. Can the negative behavior, like brand avoid or brand dislike in the previous periods, speed be moved to more extreme points, due to current message density and speed of communication? This question is main research question of this study as brand hate and brand switch variables are included in model. Next sections include theoretical background of concept and methodology of study. The study employs logistic regression and Mann Whitney Test for examining relationship and differences regarding to variables. Contextual conclusions regarding to Turkey market are useful for managerial implications as they signal structure of Turkish consumer's negativity towards brands. 


\section{LITERATURE REVIEW}

Consumer negativity refers to any negative intention, attitude or opinion towards brand. As a negative concept, it has several antecedents and consequences related to market based, product/service based and consumer based variables. This study mainly focuses on consequences of consumer negativity while it includes brand hate and brand switch constructs as consequences of three antecedents.

Brand hate is one sub concept in consumer negativity concept. It is defined by Kucuk (2016) as;

"as a psychological state whereby a consumer forms intense negative emotions and detachment toward brands that perform poorly and give consumers bad and painful experiences on both individual and social levels."

Fetscherin and Heinrich (2014) examine consumer-brands relationship and include a brand feeling matrix consists of strenghts of brand relationship (weak / strong) and feeling towards brand. Brand hate is included in strong relationship and negative feeliing towards brand, while weak negative relationship is included as brand avoidance.

On the other hand brand switch mainly relates to intention side of negativity. It refers to changing intention of preferred brand related to several motivations. Keaveney (1995) examines brand switch in service companies' context and concludes eight factors related to switching. These factors are; pricing, core service failure, inconvenience, service encounter failures, response to service failure, competition, involuntary switching and ethical problems.

\section{DATA AND METHODOLOGY}

Survey methodology with convenience sampling is employed for evaluating consumer negativity. Students are selected for sample population and 135 participants answered survey of study. According to Hair et al. (2014) five participants for each item is required for minimum requirements of factor analysis, survey with 27 items and 135 participants comply with this requirement. First part of survey consists of demographic factors and relationship questions regarding to brand which participant has negativity towards. Table 1 shows that most of participants have female, $18-25$ age and single marital status characteristics. Total relationship period of participants are +7 years mostly and total negative relationship are $0-1$ and $2-3$ years mostly.

Table 1: Descriptive Statistics for Participants

\begin{tabular}{lccccc}
\hline Characteristics & N & Percentage & & N & Percentage \\
\hline Gender & & & Total Relationship with Brand & \\
\hline Female & 89 & 65.9 & $2-1$ Years & 25 & 18.5 \\
\hline Male & 46 & 34.1 & $4-5$ Years & 27 & 22 \\
\hline Age Group & & & $6-7$ Years & 16.3 \\
\hline $18-25$ & 70 & 51.9 & +7 Years & 14.4 \\
\hline $26-30$ & 35 & 25.9 & Total Negative Relationship with Brand & 47 & 34.8 \\
\hline $31-40$ & 20 & 14.8 & 0-1 Years & 42 & 31.1 \\
\hline 40 and 40+ & 8 & 5.9 & $2-3$ Years & 42 & 31.1 \\
\hline Missing & 2 & 1.5 & $4-5$ Years & 24 & 17.8 \\
\hline Marital Status & & & $6-7$ Years & 7 & 5.2 \\
\hline Single & 114 & 84.4 & +7 Years & 20 \\
\hline Married & 21 & 15.6 & & 14.8 \\
\hline
\end{tabular}

First part of survey also included name of brand which users have negativity towards. Most of brands included are telecommunication brands (29), clothing (27), food (21) and technology (17). Second part of survey included survey items for study constructs. Negative past experience, symbolic incongruity, ideological incongruity and negative e-wom questions are used from Hegner et al. (2017)' study. Hegner et al.(2017) adapted items of Lee et al. (2007) in their study. Brand hate construct items are used from Hegner et al.(2017)'s study, in that study authors identified 6 items for brand hate. Lastly, brand switch questions used from Romani et al. (2012)'s study, Romani et al. (2012) referenced Bougie et al. (2012)'s study for items.

Hypotheses of study are;

$\mathrm{H}_{1}$ : Negative past experience, symbolic incongruity and ideological incongruity are positively related to brand hate.

$\mathrm{H}_{2}$ : Negative past experience, symbolic incongruity and ideological incongruity are positively related to brand switch.

$\mathrm{H}_{3}$ : There is significanlty difference for e-wom between brand hate values.

$\mathrm{H}_{4}$ : There is significanlty difference for e-wom between brand switch values.

The study uses non-parametric methods for evaluating hypotheses due to abscence of normal distribution, thus logistic regression and MannWhitney Test is employed. (Brand hate construct: Kolmogorov-Smirnov=0,000, Shapiro-Wilk=0,000, Skewness=-0,268, Kurtosis=-0,971, Brand switch construct: Kolmogorov-Smirnov= 0,000, Shapiro-Wilk=0,000, Skewness=-1,505, Kurtosis=-2,143) 


\section{FINDINGS AND DISCUSSIONS}

Mean values are calculated for brand hate construct and values are coded as binary, regarding to mean value of 3.4641 . Hoshmer and Lemeshow values are found as 0,668 and logistic regression results conclude that dependent variable (brand hate) is explained by independent variables 33.9\% (Cox \& Snell R Square) and 45.2\% (Nagelkerke R Square).

Findings of first hypothesis logistic regression can be summarized as following formula;

$$
\ln \frac{\text { possibility of brand hate }}{1-P}=-7.876+0,896 * \text { Ideological Congruity }+0,577 \text { Symbolic Congruity }+0,545 \text { Negative Past Experience }
$$

For the second hypothesis, 4.3210 mean value is used for brand switch construct for coding. Hoshmer and Lemewshow values are found as 0,389 and logistic regression results conclude that dependent variable (brand hate) is explained by independent variables $15.7 \%$ (Cox \& Snell R Square) and $21.5 \%$ (Nagelkerke R Square).

Findings of second hypothesis logistic regression can be summarized as following formula;

$$
\ln \frac{\text { possibility of brand switch }}{1-P}=-3.809+0,532 \text { Symbolic Congruity }+0,424 \text { Negative Past Experience }
$$

Testing of hypotheses 3 and 4 are employ Mann-Whitney Test. It was found that there are statistically significant differences (Sig= 0.001 , $\mathrm{p}<0.05$ for hypothesis 3 , Sig= $0.000, p<0.05$ for hypothesis 4$)$. Hypothesis 3 concludes that participants with brand hate have higher negative e-wom values than participants with no brand hate $(M=4.43$ and $M=3,36)$. Hypothesis 4 concludes that participants with brand switch intention have higher e-wom values than participants with no brand switch intention $(M=4.24$ and $M=3.26)$

\section{CONCLUSION}

This study contributes to consumer negativity concept by examining brand switch and brand hate concepts together for Turkish consumer context. The study finds that three antecedents of brand hate as confirms previous literature. Negative past experience, symbolic incongruity and ideological incongruity are found as antecedents of brand hate. Brand switch has two antecedents, while remaining antecedent (ideological incongruity) only affects brand hate. Thus, ideological incongruity has only affect on concept with attitude nature (brand hate), not on concept with intention attitude (brand switch).

The study also compares brand hate and brand switch concepts regarding to negative e-wom consequence. Statistically significant differences are concluded regarding to negative e-wom. This signal potential of these two negative constructs for negative consequences.

Telecommunication, clothing, food and technology are found most consumer negativity emotions brands. These industries can contribute to further researches involving consumer negativity for Turkish consumer context. Research questions regarding to; motivations of consumer negativity among industries, consequences of negativity for different industries can be helpful for future research.

\section{REFERENCES}

Bougie, R., Pieters, R., \& Zeelenberg, M. (2003). Angry customers don't come back, they get back: The experience and behavioral implications of anger and dissatisfaction in services. Journal of the Academy of Marketing Science, 31(4), 377-393.

Canbolat, Z.N \& Pınarbaşı, F. (2018). Mobil Uygulamalara Yönelik Olumsuz Kullanıcı Değerlendirmelerinin İncelenmesi: İçerik Analizi ve Metin Madenciliği Yöntemleriyle Bir Uygulama. V. Yıldız Sosyal Bilimler Kongresi, 102.

Fetscherin, M., \& Heinrich, D. (2014). Consumer brand relationships: A research landscape. Springer.

Hair, J. F., Black, W. C., Babin, B. J., \& Anderson, R. . (2014). Multivariate Data Analysis (7. bs). Pearson.

Hegner, S. M., Fetscherin, M., \& van Delzen, M. (2017). Determinants and outcomes of brand hate. Journal of Product \& Brand Management, 26(1), 13-25.

Keaveney, S. M. (1995). Customer switching behavior in service industries: An exploratory study. The Journal of Marketing, 71-82.

Kucuk, S. U. (2016). Brand Hate: Navigating Consumer Negativity in the Digital World. Palgrave Macmillan, Cham.

Lee, M. S., Motion, J., \& Conroy, D. (2009). Anti-consumption and brand avoidance. Journal of Business Research, 62(2), 169-180.

PInarbaşı, F., \& Canbolat, Z. N. (2018). EVALUATION OF AUGMENTED REALITY MOBILE APPLICATIONS IN TURKEY MARKET: A DATA MINING APPROACH TO CONSUMER REVIEWS. CHANGING ORGANIZATIONS, 187.

Romani, S., Grappi, S., \& Dalli, D. (2012). Emotions that drive consumers away from brands: Measuring negative emotions toward brands and their behavioral effects. International Journal of Research in Marketing, 29(1), 55-67. 